\title{
MCA-KIPA ANALYSIS OF MILITARY TRANSPORT
}

\author{
Adrienn Boldizsár ${ }^{1}$, Botond Kővári ${ }^{2}$, Ferenc Mészáros ${ }^{3}$ \\ ${ }^{1,2,3}$ Department of Transport Technology and Economics, Faculty of Transport Engineering and Vehicle \\ Engineering, Budapest University of Technology and Economics, H-1521 Budapest, P.O.B. 91, Hungary \\ 1 Department of Management Sience and Logistics, Gamf Faculty of Engineering and Computer Science, \\ John Von Neumann University, H-6000 Kecskemét, Izsáki st. 10., Hungary
}

Received 4 December 2018; accepted 9 January 2019

\begin{abstract}
Military transport is as old as warfare itself, as rations, weaponry and other necessary equipment had to be provided for the soldiers even in ancient times. Military transport has a long history through the ages since the spread of wars involving long distance troop movements the transportation of soldiers, sustenance, weaponry and equipment for camp placement has become increasingly important. It is defined as the transfer of higher unit, unit, subunit, institutions, subdivisions, military materials and technical devices from one area to another through various transport sectors. Moreover, military transport includes not only the transfer of materials and devices but the transportation of personnel as well. The paper examined the strategic significance of each mode of transport at the army. Therefore, the KIPA analysis was performed for prioritisation, which was used to determine the transport sector that has the greatest role in the life of the army.
\end{abstract}

Keywords: military transport, strategic transport, KIPA analysis, aerial military transport.

\section{Introduction}

The transport and accumulation of the strategic stock and the satisfaction of a given military operation's stock, fuel, spare part, ammunition and provision demand requires precise and high capacity logistics. Naturally, the difficulty of a certain task depends on several factors for example speed and the size of the army deployed to the field and the length of the operation. The efficiency of strategic transports depends on the kind of infrastructure available for the troops (Moretti et al., 2018).

\section{Presentation of Strategic Transport by Transport Sectors}

Following we can see in detail the strategic transport by transport sectors in the life of army.

\subsection{Strategic Transport on Water}

The best case scenario for military logistics personnel is if well-established ports are available which are capable of receiving several low-hulled vessels nearby to the destination. Strategic naval transport can be divided into a few groups. One of these branches is the American Military Sealift Command's forward storage vessel system. Essentially, vessels are positioned at strategic points of the ocean with enough equipment, fuel and ammunition to last 30 days for the navy to execute both aerial or land operations. As each ship is equipped with its' own crane system, the usage of adequate ports is possible.

The other naval transport possibility is the transport vessels that make up the backbone of strategic transport. Container transport

\footnotetext{
${ }^{1}$ Corresponding author: boldizsar.adrienn@gamf.uni-neumann.hu
} 
vessels, tanker ships and Ro-Ro floating units-specially designed units capable of transporting vehicles and helicoptersare widely used by military forces with sufficient coastline, navy and ability to lead expeditions. The system's main liability is vulnerability; a well-executed attack could lead to the destruction of essential supplies (Trautmann, 2016).

\subsection{Aerial Strategic Transport}

If the destination country does not have a coastline or a port at its' disposal, strategic aerial transportation might be the best solution. However, this is the most expensive approach out of all the possibilities and only a limited number of countries possess aeroplanes suitable of real aerial transport. Not to mention, only a few countries manufacture them. AN-225 Mrija, the largest strategic aerial transport plane.

Strategic aerial planes are capable of transporting even heavy military vehicles. Airports are the only stable and safe transportation possibility in Afghanistan. Even though the path starting from Pakistan leading through the Khyber Pass would be a considerably cheaper route it's also much more dangerous as countless trucks and deliveries have been high-jacked by armed Taliban attackers. Another important factor to take into consideration is the refuelling of the planes. The possible range of each laden plane decreases as the effective load is divided between the cargo and the fuel (Thayer, 1965).

\subsection{Strategic Railway Transport}

Railway transportation could be the ideal compromise in principle considering it encapsulates the load capability and inexpensive cost per tonne of naval transport and the swiftness of aerial transport (Nesic et al., 2017). Though, this means of transport is only credible in cases of continental conveyance or countries with an advanced infrastructure however these are not the areas that are in need of this transport. The EU's well-established railway system is taken into account by the NATO's North European defence plans and other countries rely on their own railways like Japan, China, Russia etc. However, there are a number of operative areas with virtually no or hardly any railway lines equipped with sufficient load capacity and reliable rolling stock (locomotives, freight wagons, trolleys) can be found. Afghanistan, Iraq, or most of Africa, are not part of the area with the appropriate infrastructure (Trautmann, 2016).

The best delivery is the one that has already been done, which means that strategic stock has previously been accumulated for future application areas. This solution makes a more flexible and faster start of an operation possible, since only the soldiers have to be delivered to the scene. The US military has built several similar forward depots around the world from the Middle East through Europe to Asia. As a result of increased Russian threat, Americans, for example, have relocated the installation of a completely mechanized brigade to Europe, but its' supervision, the continuous maintenance of equipment and vehicles stored there, and the task of keeping them in combat ready condition requires both man and financial power. At the same time, reparation of vehicles in the depot's maintenance centre is still much cheaper and simpler than for example carrying a brigade worth of military vehicles across the Atlantic two at a time by cargo planes (Van Eekeren et al., 2018). 


\section{KIPA Analysis of Methods of Military Transport}

The KIPA method was developed at the Budapest University of Technology and Economics, the acronym comes from the names of its' creators József Kindler and Ottó Papp. Based on its basic philosophy, it can be classified into European schools, which examines the advantages and disadvantages of the systems to be compared with each other. It also determines the order of preference based on the benefits and disadvantages. As a result, the literature uses the term "optimum" instead of „better” and looks for an optimal solution from the set of alternatives (Kindler and Papp, 1977).

The method characterized by a five-stage verbal scale based on the considerations of the comparable alternatives. The scales ratio is usually determined by the weighting process, that is the scale unit usually suggests the weight itself. This means that the bad grade is zero-point, the corresponding grade is the weighting value itself, the middle grade is two times its' weight, the good grade is three times its weight, and the very good grade is four times the weight. Table 1 . shows the basic table of KIPA (Esztergár-Kiss and Csiszár, 2012).

Table 1

The Basic Table of KIPA

\begin{tabular}{|c|c|c|c|c|c|c|}
\hline \multirow{4}{*}{ Alternatives } & \multicolumn{6}{|c|}{ Viewpoints and weightings } \\
\hline & \multicolumn{2}{|c|}{$\mathrm{C}_{1}$} & \multirow{2}{*}{\multicolumn{2}{|c|}{$\cdots$}} & \multicolumn{2}{|c|}{$\mathrm{C}_{\mathrm{i}}$} \\
\hline & \multicolumn{2}{|c|}{$\mathrm{w}_{1}$} & & & \multicolumn{2}{|c|}{$w_{j}$} \\
\hline & verbal & value & verbal & value & verbal & value \\
\hline$A_{1}$ & & $\mathrm{p}_{11}$ & & & & \\
\hline \multicolumn{7}{|c|}{$\ldots$} \\
\hline$A_{i}$ & & & & & & $\mathrm{p}_{\mathrm{ij}}$ \\
\hline
\end{tabular}

Source: (Own Editing).

It is calculated by adding the weight of the criteria, where $A_{i}$ is preferred or indifferent to $A_{j}$, and the amount is divided by the sum of the weight numbers.

\subsection{Calculation}

To perform the KIPA method we first determined the comparative alternatives, in this case the military transport sectors:

- $\mathrm{A}_{1}=$ road military transport;

- $\mathrm{A}_{2}=$ air military transport;

- $\mathrm{A}_{3}=$ railway military transport;

- $\mathrm{A}_{4}=$ waterborne military transport.

To this end, we defined an 8 viewpoints system, which can be used to compare each transport sector, as a result, which sector is "optimal" or most appropriate for carrying out military deliveries (Ivković et al., 2018). The considerations are as follows:

- $\mathrm{C}_{1}=$ cost, how expensive it is to transport the unit of goods;

- $\mathrm{C}_{2}=$ investment demand for proper operation;

- $\quad \mathrm{C}_{3}=$ energy demand (fuel);

- $\mathrm{C}_{4}=$ capacity constraint of a given transport;

- $\mathrm{C}_{5}=$ speed;

- $\mathrm{C}_{6}=$ applicability of dangerous or combat areas;

- $\quad \mathrm{C}_{7}=$ special tooling for the removal of military materials; 
- $\mathrm{C}_{8}=$ making great distances is the most efficient way.

For the analysis, the weight of the specified criteria must be given, as well as the comparisons done in Table 2, which has been studied in the most objective way possible through various expert opinions and the studies we have done so far. The weights were determined on a scale of 5,5 being the worst and 40 the best (Karádi et al., 2015), (Bölükbaş et al., 2012).

\section{Table 2}

Comparison Table for Weight Numbers and Alternatives

\begin{tabular}{|c|c|c|c|c|c|}
\hline Viewpoints & Weighting & $\mathbf{A}_{1}$ & $\mathbf{A}_{2}$ & $\mathbf{A}_{3}$ & $\mathbf{A}_{4}$ \\
\hline $\mathbf{C}_{\mathbf{1}}$ & $\mathbf{5}$ & large & very large & average & low \\
\hline $\mathbf{C}_{\mathbf{2}}$ & $\mathbf{2 0}$ & average & large & large & low \\
\hline $\mathbf{C}_{3}$ & $\mathbf{1 5}$ & large & large & average & low \\
\hline $\mathbf{C}_{\mathbf{4}}$ & $\mathbf{3 0}$ & low & average & very large & very large \\
\hline $\mathbf{C}_{5}$ & $\mathbf{4 0}$ & average & very large & large & low \\
\hline $\mathbf{C}_{\mathbf{6}}$ & $\mathbf{3 5}$ & large & very large & average & low \\
\hline $\mathbf{C}_{7}$ & $\mathbf{2 5}$ & low & large & average & very large \\
\hline $\mathbf{C}_{\mathbf{8}}$ & $\mathbf{1 0}$ & low & veri large & average & large \\
\hline
\end{tabular}

Source: (Own Editing).

With the help of this table, the performance of later analysis will be easier. For weights, we chose 5 as the scale's unit for easy calculation. According to the principle of KIPA, and in the comparative table, we can see in the basic tables defined in Table $3 / a$ and $b$, for better transparency it is represented in two parts (Gyarmati, 2003; Heinitz and Hirschberger, 2017).

\section{Table 3/a}

The First Half of the Defined KIPA Basic Table

\begin{tabular}{|c|c|c|c|c|c|c|c|c|}
\hline & \multicolumn{8}{|c|}{ Viewpoints/Weightings } \\
\hline & \multicolumn{2}{|c|}{$\mathrm{C}_{1}$} & \multicolumn{2}{|c|}{$\mathrm{C}_{2}$} & \multicolumn{2}{|c|}{$\mathrm{C}_{3}$} & \multicolumn{2}{|c|}{$\mathrm{C}_{4}$} \\
\hline & \multicolumn{2}{|c|}{$\mathrm{U} 1(5)$} & \multicolumn{2}{|c|}{ U2 (20) } & \multicolumn{2}{|c|}{ U3 (15) } & \multicolumn{2}{|c|}{ U4 (30) } \\
\hline Alternatives & Verbal & Value & Verbal & Value & Verbal & Value & Verbal & Value \\
\hline $\mathbf{A}_{1}$ & average & 10 & good & 60 & acceptable & 15 & acceptable & 30 \\
\hline $\mathbf{A}_{2}$ & acceptable & 5 & acceptable & 20 & average & 30 & average & 60 \\
\hline $\mathbf{A}_{3}$ & good & 15 & averages & 40 & good & 45 & good & 90 \\
\hline $\mathbf{A}_{4}$ & very good & 20 & very good & 80 & very good & 60 & very good & 120 \\
\hline
\end{tabular}

Source: (Own Editing) 


\section{Table 3/b}

The Second Half of the Defined KIPA Basic Table

\begin{tabular}{|c|c|c|c|c|c|c|c|c|}
\hline & \multicolumn{8}{|c|}{ Viewpoints/Weightings } \\
\hline & \multicolumn{2}{|c|}{$\mathrm{C}_{5}$} & \multicolumn{2}{|c|}{$\mathrm{C}_{6}$} & \multicolumn{2}{|c|}{$\mathrm{C}_{7}$} & \multicolumn{2}{|c|}{$\mathrm{C}_{8}$} \\
\hline & \multicolumn{2}{|c|}{ U5 (40) } & \multicolumn{2}{|c|}{ U6 (35) } & \multicolumn{2}{|c|}{ U7 (25) } & \multicolumn{2}{|c|}{ U8 (10) } \\
\hline Alternatives & Verbal & Value & Verbal & Value & Verbal & Value & Verbal & Value \\
\hline $\mathbf{A}_{1}$ & average & 80 & good & 105 & very good & 100 & acceptable & 10 \\
\hline $\mathbf{A}_{2}$ & very good & 160 & very good & 140 & good & 75 & very good & 40 \\
\hline $\mathbf{A}_{3}$ & good & 120 & average & 70 & average & 50 & average & 20 \\
\hline $\mathbf{A}_{4}$ & acceptable & 40 & acceptable & 35 & acceptable & 25 & good & 30 \\
\hline
\end{tabular}

Source: (Own Editing)

As a next step for producing the KIPA matrix is calculating the preference indicators, $c_{i j}$, and the disqualification indicators, $d_{i j}$.

The benefit indicator examines the benefits of $i$-th alternatives to $j$-eds and is calculated for each and every relation. Its value comes from summing up the percentages of the valuation criteria, for which the initial alternative is preferred or indifferent (the value added in the base table is greater than or equal to) to the compared alternative. The downside indicators are also calculated for all ij ratios, but the calculation should take into account that only the evaluation aspect for which preference intensity is the highest. The calculation of the benefit and deficit indicators is not specified in the article. The advantage and downside indicators can be used to produce the KIPA matrix, which is included in Table 4.

Table 4

The Generated KIPA Matrix with Percentages

\begin{tabular}{|c|c|c|c|c|}
\hline & $\mathbf{A}_{\mathbf{1}}$ & $\mathbf{A}_{\mathbf{2}}$ & $\mathbf{A}_{3}$ & $\mathbf{A}_{4}$ \\
\hline \multirow{2}{*}{$\mathbf{A}_{\mathbf{1}}$} & & 27,78 & 44,44 & 55,56 \\
\cline { 5 - 6 } & & 25 & 18,75 & 18,75 \\
\hline \multirow{2}{*}{$\mathbf{A}_{2}$} & 72,22 & & 61,11 & 61,11 \\
\cline { 2 - 3 } \cline { 5 - 5 } & 12,5 & & 18,75 & 18,75 \\
\hline \multirow{2}{*}{$\mathbf{A}_{3}$} & 55,56 & 38,89 & & 55,56 \\
\cline { 2 - 4 } & 15,63 & 21,88 & & 12,5 \\
\hline \multirow{2}{*}{$\mathbf{A}_{4}$} & 44,44 & 38,89 & 44,44 & \\
\cline { 2 - 4 } & 15,63 & 25 & 25 & \\
\hline
\end{tabular}

Source: (Own Editing) 
The ranking of the preference order and the ranking of transport sectors can be based on the data of the matrix. The preference threshold is 60 percent, so $c_{i j} \geq 60 \%$ and the disqualification threshold at $30 \%, \mathrm{~d}_{\mathrm{ij}}$ $\leq 30 \%$, which level was a total of 3 pairs of comparisons (green in the table). With these, the assortment graph can also be plotted, the vertices of the graph are made up of the alternatives, the comparable element was controlled by pairs of pairs, they start from the preferred alternative and point to the other member. The graph can be used to determine the order of variations and to illustrate the results, the best alternative is the one all the arrows are pointing from and the worst version is the one most of the arrow are pointing at. Fig 1. shows assortment graph of the KIPA analysis.

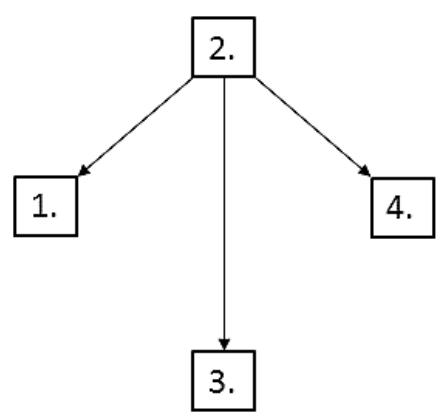

Fig. 1.

Assortment Graph of the KIPA analysis Source: (Own Editing)

As a result of the KIPA analysis we have found that air transport is the most optimal for the army, taking into account the specificities of military transport. It also confirms why the development of the cargo plane fleet is an important topic for the Hungarian Defence Forces.

\section{Conclusion}

In the article we examined the strategic significance of each mode of transport at the army, and KIPA analysis was performed for prioritisation, which was used to determine the transport sector that has the greatest role in the life of the army. In order to make the calculation, we took into account 8 criteria as a function of the factors that best determine the choice between the different transport sectors. As a result of this calculation, we have found that military air transport is the most favourable transport sector to serve today's military operations. At the same time, you should not forget the other modes of transport, especially in a small country like Hungary. It is not possible to rely on just one strategic transport, although the analysis has proved that, that today's air transport capacity is very important and is an indispensable investment in our country. Today's efforts to develop air capacity are very important steps to be a strong and independent army for our country. 


\section{References}

Bölükbaş, U.; Çelik, E.; Güneri, A.F. 2012. Performance evaluation of Turkish retail firms using the fuzzy AHP, PROMETHEE, ELECTRE and VIKOR methods. In Proceedings of the 10th International FLINS Conference, Uncertainty Modeling in Knowledge Engineering and Decision Making, 243-248. doi: 10.1142/9789814417747_0040.

Bridges, E.; Evers, K. 2009. Wartime critical care air transport, Military medicine 174(4): 370-375. doi: 10.7205/MILMED-D-03-9607.

Esztergár-Kiss, D.; Csiszár, C. 2012. Analysis of multimodal journey planners using a multi-criteria evaluation method, In Proceedings of the 19th ITS World Congress, Vienna, Austria, 1-12.

Gyarmati, J. 2003. Application of the Multi-Criteria Decision Theory in Comparison of the Military Technology Devices [in Hungarian: Többszempontos döntéselmélet alkalmazása a haditechnikai eszközök összehasonlitásában], $\mathrm{PhD}$ Dissertation. Budapest, Zrínyi Miklós National Defense University, Department for Military Technology and Quality. Available from internet: <http://193.224.76.2/ downloads/konyvtar/digitgy/phd/2003/gyarmati_ jozsef.pdf $>$.

Heinitz, F.; Hirschberger, M. 2017. Stated in-flight service preferences for short to medium-haul air trips, International Journal of Aviation Management 4(1-2): 3-28. https://doi.org/10.1504/IJAM.2017.089438.

Ivković, I.; Čokorilo, O.; Kaplanović, S. 2018. The estimation of GHG emission costs in road and air transport sector: case study of Serbia, Transport 33(1): 260-267. https://doi.org/10.3846/16484142.2016.1 169557.
Karádi, D.; Csiszár, C.; Nagy, E. 2015. Integrated information application on mobile devices for air passengers. In Proceedings of the International Conference Models and Technologies for Intelligent Transportation Systems (MT-ITS), 304-311.

Kindler, J.; Papp, O. 1977. Study of Complex SystemsMatching Methods [in Hungarian: Komplex rendszerek vizsgálata-Összemérési módszerek]. Technical Publishing House [in Hungarian: Műszaki Könyvkiadó], Budapest, 151-175.

Moretti, L.; Di Mascio, P.; Nichele, S.; Cokorilo, O. 2018. Runway veer-off accidents: quantitative risk assessment and risk reduction measures, Safety science 104: 157-163.

Nešić, A.; Čokorilo, O.; Steiner, S. 2017. Aircraft Repair and Withdrawal Costs Generated by Bird Collision with the Windshield, Promet-Traffice Transportation 29(6): 623-629.

Thayer, F. C. 1965. Air Transport Policy and National Security: A Political, Economic, and Military Analysis. Chapel Hill, NC: University of North Carolina Press.

Trautmann, B. 2016. Strategic Transport [in Hungarian: A mozgatók - stratégiai szállítmányozás]. Availbale from Internet: <https://honvedelem.hu/cikk/59916_a_ mozgatok>. last visit: 8 January 2019, 14:26.

Van Eekeren, R.; Wright, S.; Čokorilo, O. 2018. Early cost safety analysis of runway events, International Journal for Traffic and Transport Engineering 8(3): 261-270. doi: 10.7708/ijtte.2018.8(3).01. 